\title{
Investigation of the Geology and Hydrology of the Coconino Plateau of Northern Arizona: A Project of the Arizona Rural Watershed Initiative
}

Th Plateau in northern Arizona are under increasing demand as a result of development. The population of this arid region continues to grow, and the number of visitors to the many national and state parks and monuments in the region has increased annually. The sustainability, protection, and maintenance of springs and seeps and associated riparian habitat on the Coconino Plateau are major issues that have broad public and governmental support.

Regional stakeholders agree that an improved understanding of the regional hydrogeologic system is needed to address the concerns of water supply and ground-water sustainability. The base of information required to adequately describe the hydrogeology of the Coconino Plateau currently does not exist. Hydrogeologic data is most abundant for large population centers like Flagstaff and Sedona, but is sparse for less populated areas like Williams, Tusayan, Valle, and Cameron. There are still large parts of the Coconino Plateau for which there is no basic geologic or hydrologic information available. In order to develop a hydrogeologic framework for the Coconino Plateau, a comprehensive effort is needsd to compile existent data and collect additional data to fill in data gaps and reinforce limited information.

In 1999, the U.S. Geological Survey (USGS) began an assessment of the hydrogeology of the Coconino Plateau in cooperation with the Arizona Department of Water Resources (ADWR) as part of the Rural Watershed Initiative, a program established by the State of Arizona and managed by the ADWR. Assessments also are underway in the upper-middle Verde River watershed (Woodhouse and others, 2002) to the south and in the Mogollon Highlands to the southeast (Parker and Flynn, 2000).
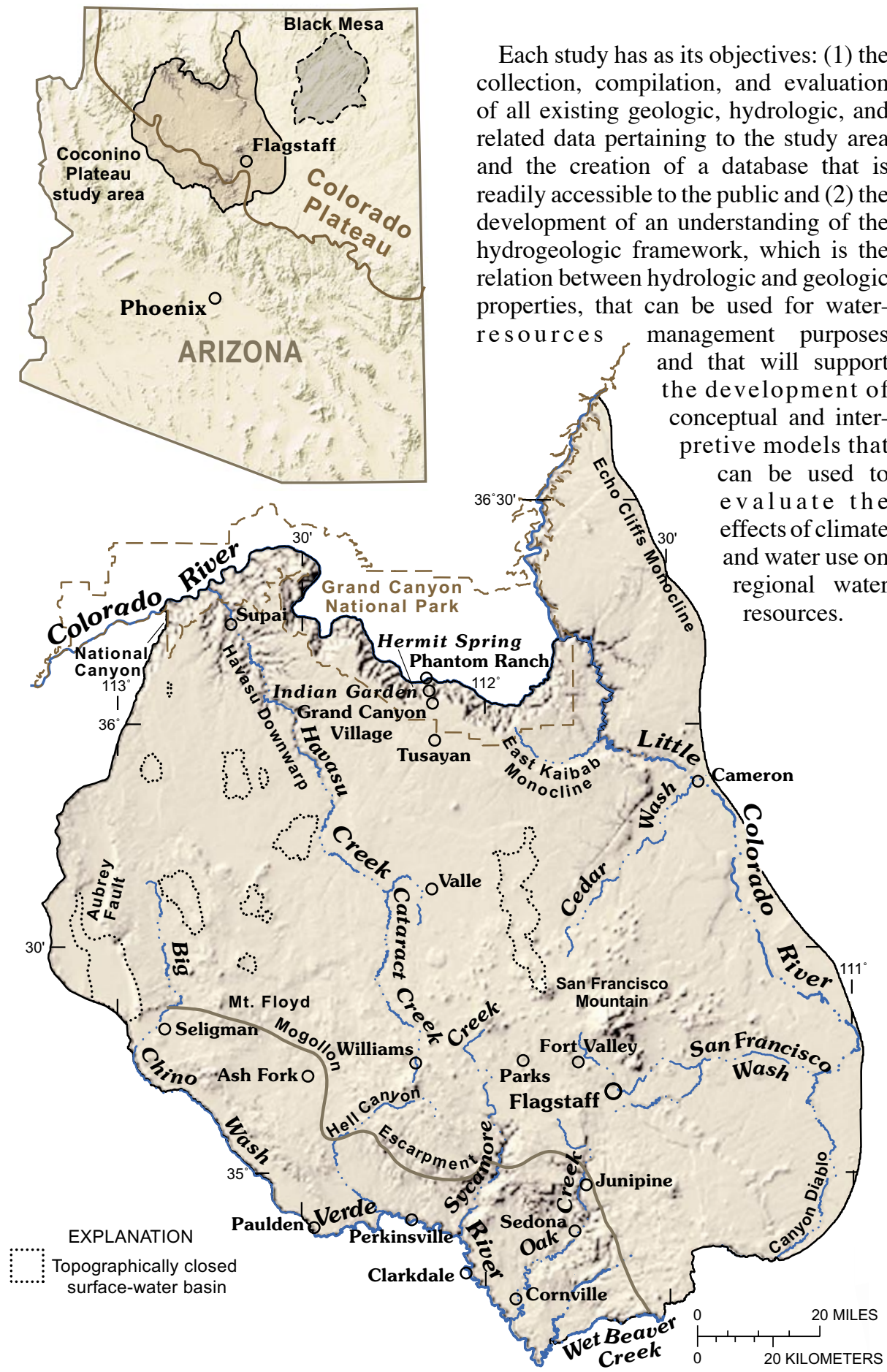

Figure 1. Location of the Coconino Plateau study area.
Each study has as its objectives: (1) the collection, compilation, and evaluation of all existing geologic, hydrologic, and related data pertaining to the study area and the creation of a database that is readily accessible to the public and (2) the development of an understanding of the hydrogeologic framework, which is the relation between hydrologic and geologic properties, that can be used for waterresources, management purposes and that will support conceptual and interpretive models that can be used to evaluate the effects of climate and water use on regional water resources. 


\section{Physical Setting}

The Coconino Plateau is a subprovince of the Colorado Plateau in north-central Arizona, south of the Colorado River (fig. 1). The study area encompasses about 10,300 square miles in northern Arizona, including all of the Coconino Plateau and parts of the Little Colorado River and Verde River Basins. The study area is bounded by the Colorado River on the north, the Aubrey Fault on the west, the Verde River and Wet Beaver Creek on the south, and the Echo Cliffs Monocline and western edge of the Black Mesa Basin on the east (fig. 1). These features partly control the regional occurrence and movement of ground water and can be used to define the hydrogeologic boundaries of the study area. The main area of focus for this study is the Coconino Plateau.

The Coconino Plateau is dominated by a high, dry, desert-type environment with alpine conditions at higher altitudes. Average annual temperature ranges from $43^{\circ} \mathrm{F}$ at Fort Valley on the southwest flank of San Francisco Mountain to $68^{\circ} \mathrm{F}$ at Phantom Ranch at the bottom of the Grand Canyon. Average annual precipitation ranges from 5.5 in. at Cameron at the eastern edge of the area to 27.7 in. at Junipine. Precipitation generally is less than $15 \mathrm{in}$. per year at altitudes below 5,000 ft, and more than 25 in. per year falls at altitudes above $7,000 \mathrm{ft}$.

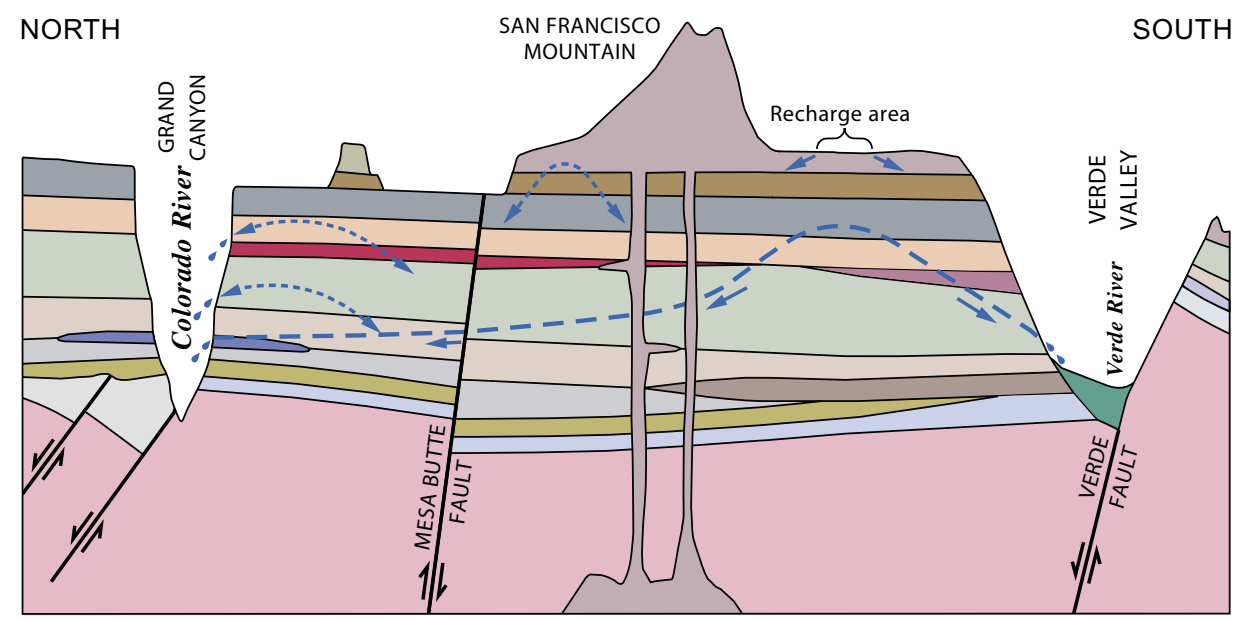

Modified from Breed and Beasley, 1975

\section{EXPLANATION}

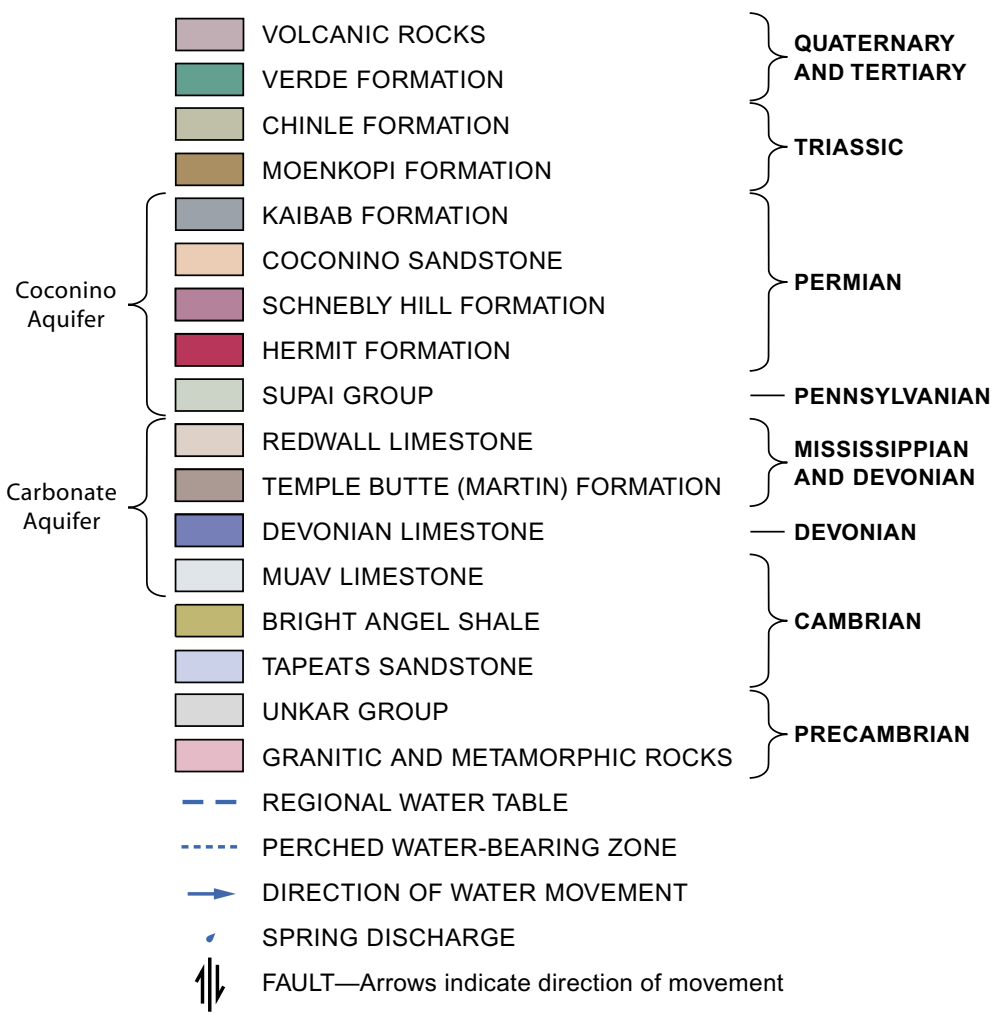

Figure 2. Generalized hydrogeologic section of the Coconino Plateau.
Above 5,000 ft, ponderosa, piñon, and juniper pines, aspen, and oak are the primary vegetation types. Below $5,000 \mathrm{ft}$, vegetation is mostly sparse grasses, brush, and other high-desert species. Riparian habitat consisting of a diverse mixture of cottonwood, ash, and sycamore with mixed brush and grass occurs throughout the Coconino Plateau at springs, seeps, and short stream segments fed by springs.

The study area includes about half of Coconino County and a small part of Yavapai County. The population of the study area increased about 20 percent from 1990 to 2000 and currently is about 78,000 ; about 80 percent live in and around the City of Flagstaff (Arizona Department of Commerce, 2000). The remainder of the population lives in rural areas and at smaller population centers, such as Williams, Valle, Tusayan, Grand Canyon Village, Parks, and Cameron.

\section{Geology}

Along the northern boundary of the study area, the Colorado River has exposed a nearly 5,000 ft thick sequence of Precambrian and Paleozoic rocks. The Precambrian rocks are the Unkar Group, granite, metamorphosed granite, schist, and gneiss exposed in deeply incised canyons tributary to the Colorado River and at the upper end of Big Chino Wash. The Paleozoic rocks are sandstone, siltstone, shale, and limestone, Early Cambrian to Permian in age, that underle almost the entire area and are exposed in deep canyons along the Colorado River and the Little Colorado River.

The Permian Kaibab Formation forms the bedrock surface over much of the Coconino Plateau. The formation has eroded over time to a landscape of low hills and shallow valleys. The erosional remnants of the Triassic Moenkopi Formation occur in places as low mesas and hills. Gravel and lacustrine deposits of Cenozoic age have infilled many of the valleys formed on the erosional surface of the Kaibab Formation to depths of one hundred feet or more. Volcanic rocks of Cenozoic age overlie sedimentary rocks of Triassic age and younger in the southern and southwestern parts of the Coconino Plateau around Mt. Floyd and San Francisco Mountain. Cenozoic travertine is present in some of the larger drainages along the south rim of Grand Canyon.

More than 3,000 $\mathrm{ft}$ of Paleozoic-age and younger rock units are exposed along the Mogollon Escarpment (Rim) at the southern edge of the study area. The Paleozoic rocks are offset as much as $500 \mathrm{ft}$ along the Aubrey Fault in the western part of the study area (fig. 1). 
Much of the eastern edge of the Coconino Plateau is defined by a series of parallel to subparallel monoclines and high-angle faults. The most prominent of these are the East Kaibab and Echo Cliffs Monoclines that have a combined relief of more than 3,000 ft (fig. 1).

Other significant structural features within the study area are the Mesa Butte Fault, the Havasu Downwarp, and breccia pipes. Breccia pipes are solution collapse features that bottom in the Redwall Limestone and stoop upward (Billingsley and others, 2000). They are significant features owing to their effects on groundwater movement and because secondary mineralization of these structures may influence water chemistry. There are also several topographically closed basins within the study area (fig. 1). These young basins are considered to be related to crustal extension still active in the area or to young karst development (George Billingsley, geologist, U.S. Geological Survey, oral commun., 2001), and could have a significant effect on the movement of ground water within the regional flow system.

\section{Hydrology}

Surface drainages on the Coconino Plateau can be divided into three general categories: (1) young, (2) mature, and (3) internal. Most of the young drainages are at the margins of the Coconino Plateau, drain north toward the Colorado River or south toward the Verde River, and are short and steep. These young drainages tend to be deeply incised into the sedimentary rocks, and springs can occur where the drainages intersect the ground-water surface. The only drainages that have the appearance of mature river valleys are the Little Colorado River, Cataract Creek, and the Verde River. These drainages are well developed and reach most parts of the Coconino Plateau. There are internal drainages on the Coconino Plateau where surface-water infiltration recharges the ground-water system locally.

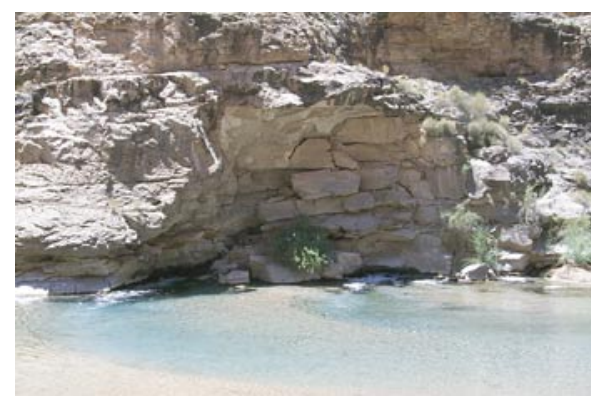

Figure 3. Blue Spring discharging to the Little Colorado River.
Ground water is known to occur in several perched water-bearing zones and two regional-flow systems on the Coconino Plateau. The extent of the perched water-bearing zones and the regional-flow systems is not defined fully, and there is little information to determine movement of water from source areas into and through these different waterbearing zones to discharge areas. The perched water-bearing zones occur discontinuously throughout the study area and are dependent on direct recharge from precipitation and runoff, which is highly variable from year to year.

The two regional flow systems found on the Coconino Plateau are the $\mathrm{C}$ aquifer (Cooley and others, 1969; Hart and others, 2002) and a carbonate aquifer. The $\mathrm{C}$ aquifer consists of hydraulically connected water-bearing zones in the Kaibab Formation, Coconino Sandstone, Schnebly Hill Formation, and sandstone layers of the Upper and Middle Supai Formations in the Flagstaff area (Bills and others, 2000). The hydrogeology of the $\mathrm{C}$ aquifer is best defined near the larger municipal areas, such as Flagstaff and Sedona. Depth to water in the C aquifer ranges from a few hundred feet to more than $1,500 \mathrm{ft}$ in these areas. Elsewhere on the Coconino Plateau, the $\mathrm{C}$ aquifer and its relation to the underlying carbonate aquifer is not well known. The carbonate aquifer, sometimes

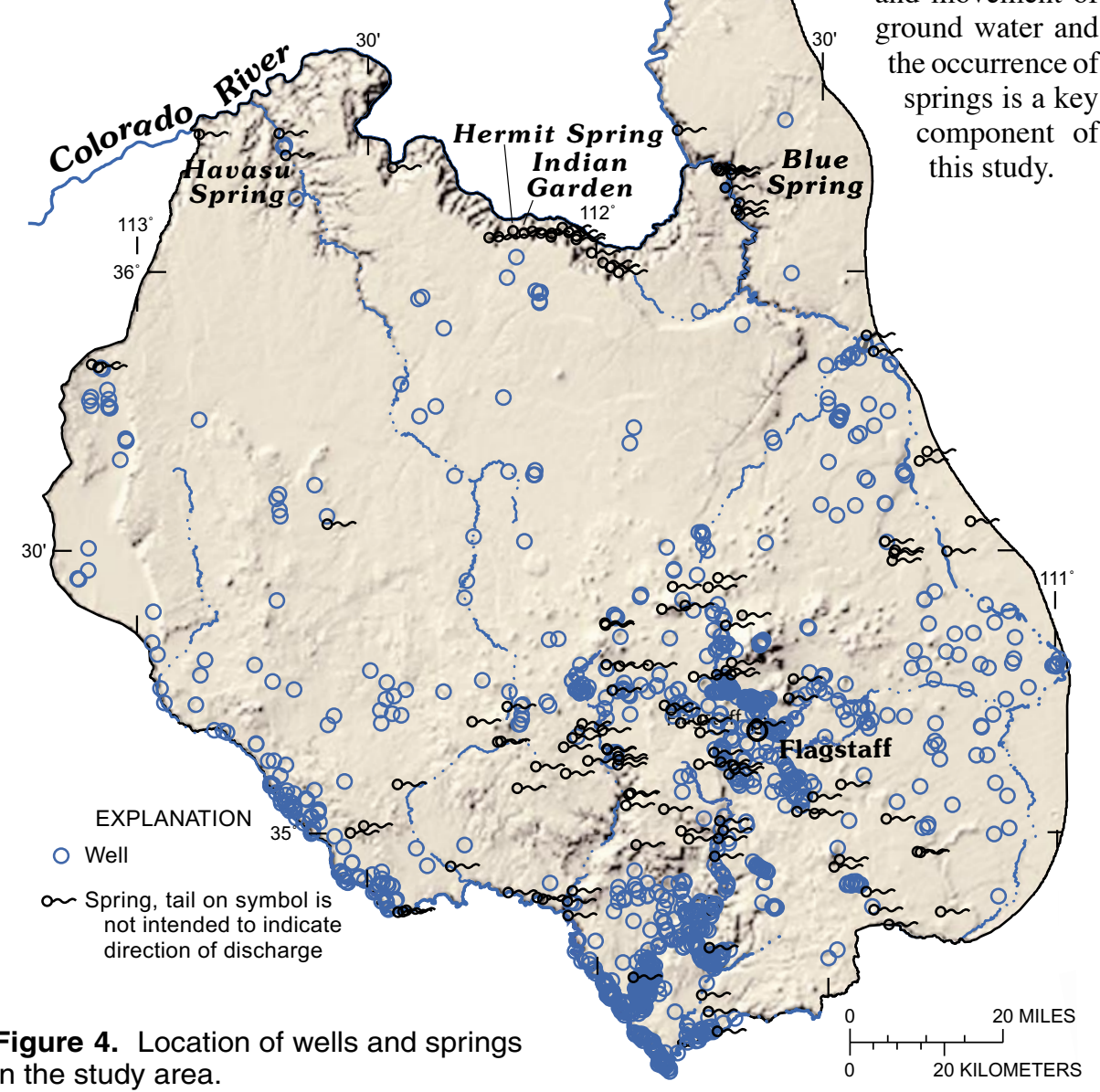

referred to as the Redwall-Muav Limestone aquifer, is composed of waterbearing zones in the Redwall and Muav Limestones and, where present, the Temple Butte Limestone/Martin Formation and other Devonian limestones (Cooley and others, 1969; Hart and others, 2002). Depth to water in the carbonate aquifer is more than $3,000 \mathrm{ft}$ below land surface in most of the study area.

Highly fractured rocks can be either conduits or barriers to the general flow of ground water, and their relation to the occurrence and movement of water in the regional flow systems is not well understood. In general, ground water is recharged by infiltration of precipitation and surface flows throughout the study area. Water that filters down to perched water-bearing zones moves laterally and vertically until it discharges at springs, encounters fractures where it can move deeper into the subsurface, or is pumped out of the ground through wells. Water that filters down to the regional aquifers moves laterally and vertically until it discharges at springs along the Little Colorado and Colorado Rivers to the north; Oak Creek, Sycamore Creek, and the Verde River to the south; or is pumped out of the ground through wells. Developing an understanding of the relation of geologic structure to the occurrence and movement of ground water and the occurrence of nt

(n)


Springs have been used and developed as an important source of water and continue to be an important physical and cultural resource to the native people of the region. In the northern part of the study area, Blue Spring (figs. 3 and 4), Havasu Spring, Indian Garden, Hermit Spring (fig. 4), and at least 20 other springs emit from the Redwall and Muav Limestones into tributary canyons in the Grand Canyon area that are approximately $3,000 \mathrm{ft}$ below the mean elevation of the Coconino Plateau. Other springs emit from the Upper and Middle Supai Formations and the Redwall and Muav Limestones that are exposed in drainages that carry water south from the Mogollon Rim into the Verde Valley, such as Oak Creek Canyon, Sycamore Canyon, and Hell Canyon. Many springs and seeps also occur in the higher elevations of the Coconino Plateau where they emit from perched water-bearing zones in unconsolidated alluvium, volcanic rocks, and consolidated sedimentary rocks. Little is known about the variability and sustainability of spring flows that maintain perennial streamflows and their attendant riparian habitat.

The USGS National Water Information System ground-water database contains data for approximately 1,390 wells and 295 springs within the study area (fig. 4). Well depths range from a few feet to $6,500 \mathrm{ft}$ below land surface, and well yields range from less than 1.0 gallon per minute (gpm) to 1,293 gpm. Spring flows range from less than $1.0 \mathrm{gpm}$ to more than $98,500 \mathrm{gpm}$.

\section{Water Use}

Ground water is the major source of public water supply in the study area. Surface-water resources are small and unreliable, and surface-water rights either are appropriated fully or under adjudication. High-yield wells are desired for public supply because of the high cost associated with drilling and developing wells that reach the regional aquifers. Municipal and commercial water suppliers delivered about 14,000 acre-ft of ground water from the regional aquifers to public and commercial customers in the area in 1999-2000, almost 60 percent more than in 1990 (ADWR, 1999). Hundreds of private wells are known to exist throughout the study area; however, the City of Flagstaff accounts for more than half of the region's ground-water use.

\section{Water Quality}

Water chemistry is varied throughout the study area. Dissolvedsolids concentrations range from 31 to 12,400 milligrams per liter.
Alkalinity ranges from 26 to 483 milligrams per liter, and $\mathrm{pH}$ ranges from 5.8 to 10.8 . In 264 of 1,364 water samples, one or more of the major ions, nutrients, trace elements, or radionuclides exceeded the U.S. Environmental Protection Agency Maximum Contaminant Levels or Secondary Maximum Contaminant Levels for drinking water.

\section{Remaining Questions}

Several questions are fundamental to understanding the hydrogeologic system of the Coconino Plateau. These questions include:

1. What are the extents of the regional aquifers within the deep-seated sandstone and limestone formations?

2. How are the $\mathrm{C}$ aquifer and the underlying carbonate aquifer hydraulically connected?

3. What is the structural framework of the regional aquifers, and how does that structure influence recharge, flow, and discharge of ground water?

4. Are there perched aquifers or other water-bearing zones that have not been identified or mapped?

5 . How do ground-water and surfacewater systems interact?

6. What is the seasonal and long-term variability of streamflow and spring flow in aquifer discharge areas?

7. How will current and projected ground-water use affect surface-water and spring resources in aquifer discharge areas?

\section{Possible Approaches}

The first 2 years of the project mainly involved the collection and compilation of existing data, identification of data needs, and the development of a hydrogeologic database. These aspects of the study are expected to continue throughout the life of the project. The collection of new data and evaluation, synthesis, and analysis of data will become increasingly important to the development of conceptual and interpretive models of the hydrogeologic system. Some of the approaches that may be used to develop conceptual and interpretive models include:

1. Synthesis and interpretation of existing and ongoing geologic mapping to develop a three-dimensional geologic framework.

2. Geophysical and geological investigations to provide information on the geometry of the ground-water basins and geologic structures that affect the direction and rate of ground-water movement.

3. Analysis of the spatial variability in geologic and structural characteristics and the relation of such characteristics to streams, springs, and wells.

4. Analysis of temporal relations among various components of the hydrologic system including precipitation, streamflow, spring discharge, and groundwater levels using new and available data.

5. Hydrochemical analyses to determine ground-water flow paths and residence times of ground water within different parts of the regional hydrogeologic system.

6. Integration of geologic and hydrologic information to develop conceptual and interpretive models of the regional hydrogeologic system.

7. Sensitivity analysis to identify those components of the regional hydrogeologic system that exert the greatest control over regional ground-water flow to aid in optimizing the collection of new data.

8. Development of an interpretive model of regional ground-water flow to examine the effects of different waterresources development scenarios on the hydrogeologic system.

-Marilyn E. Flynn and Donald J. Bills

\section{References}

Arizona Department of Commerce, 2000, accessed April 22, 2002, at URL http://www.dc.state.az.us.

Arizona Department of Water Resources, 1999 , Phase I North-Central Arizona Regional Water Study: Arizona Department of Water Resources Administrative Report, 85 p.

Billingsley, G.H., Wenrich, K.J., and Huntoon, P.W., 2000 , Breccia-pipe and geologic map of the southeastern part of the Hualapai Indian Reservation and vicinity, Arizona: U.S. Geological Survey Geologic Investigations Series I-2643, 18 p., 2 sheets, scale 1:48,000.

Bills, D.J., Truini, Margot, Flynn, M.E., Pierce, H.A., Catchings, R.D., and Rymer, M.J., 2000, Hydrogeology of the regional aquifer near Flagstaff, Arizona, 1994-97: U.S. Geological Survey Water-Resources Investigations Report $00-4122,143$ p., 4 plates.

Breed, W.J. and Beasley, Dick, 1975, Geologic cross section of Grand Canyon-San Francisco Peaks - Verde Valley Region: Zion Natural History Association, Zion National Park, Springdale, Utah, in cooperation with the National Park Service, map sheet (revised 1985)

Cooley, M.E. Harshbarger, J.W., Akers, J.P., and Hardt, W.F., 1969, Regional hydrogeology of the Navajo and Hopi Indian Reservations, Arizona, New Mexico, and Utah; with a section on vegetation by O.N. Hicks: U.S. Geological Survey Professional Paper 521-A, 61 p., 9 plates.

Hart, R.J., Ward, J.J., Bills, D.J., and Flynn, M.E, 2002, Generalized hydrogeology and ground-water budget for the $\mathrm{C}$ aquifer, Little Colorado River Basin and parts of the Verde and Salt River Basins, Arizona and New Mexico; Water-Resources Investigations Report 02-4026, 47 p., 1 plate.

Parker, J.T.C., and Flynn, M.E, 2000, Investigation of the geology and hydrogeology of the Mogollon Highlands of central Arizona: A project of the Arizona Rural Watershed Initiative: U.S. Geological Survey Fact Sheet $159-00,4$.

Woodhouse, Betsy, Flynn, M.E, Parker, J.T.C., and Hoffmann, J.P., 2002, Investigation of the geology and hydrogeology of the upper and middle Verde River Watershed of central Arizona: A project of the Arizona Rural Watershed Initiative: U.S. Geological Survey Fact Sheet 059-02, 4 p.

\section{For further information, contact:}

Marilyn Flynn

U.S. Geological Survey, WRD

2255 North Gemini Drive

Flagstaff, Arizona 86001

E-mail: meflynn@usgs.gov or visit home page

http://az.water.usgs.gov 